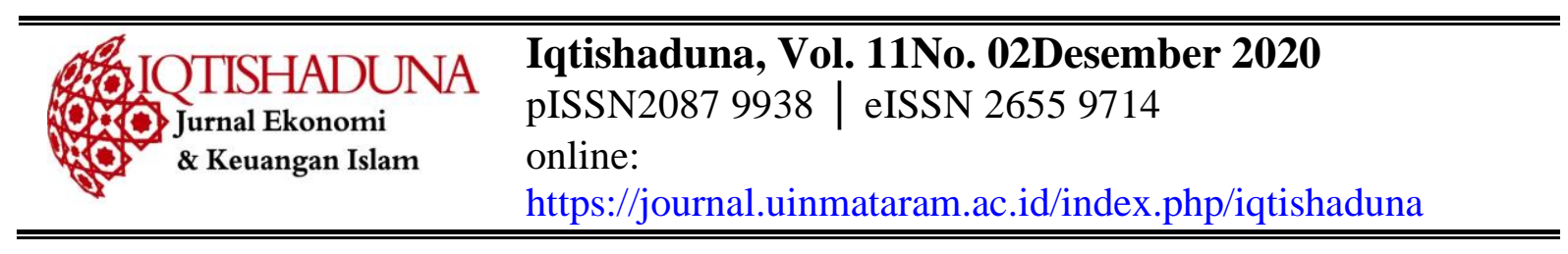

\title{
KONTRIBUSI MOTIF DAN KEYAKINAN NASABAH PADA PEMANTAPAN MINAT BERASURANSI SYARIAH DI LOMBOK
}

\author{
Umu Rosyidah \\ Universitas Islam Negeri Mataram \\ rosyidah@,uinmataram.ac.id
}

\begin{abstract}
Abstrak
Saat ini perkembangan lembaga asuransi syari'ah di Lombok cukup menggembirakan.Penelitian ini ingin mengetahui tentang faktor psikologis yang merupakan faktor pendorong dari dalam diri nasabah yang dapat berkontribusi mempengaruhi minat nasabah untuk berasuransi syariah, yaitu motif rasional dan motif emosional. Selain itu ingin mengetahui apakah faktor keyakinan nasabah di Lombok yang mayoritas muslim mempunyai kontribusi yang paling dominan. Penelitian ini mengambil sampel sebanyak 100 responden dari nasabah 8 perusahaan asuransi syariah di Lombok. Tehnik penentuan sampel yang digunakan adalah non probability sampling dan pemilihan samplenya dilakukan secara accidental sampling. Teori yang dipakai untuk membedah pokok permasalahan yang ada adalah dengan menggunakan teori pengambilan keputusan. Hasil penelitian: secara parsial motif rasional dan motif emosional berkontribusi secara signifikan pada pemantapan minat berasuransi syariah dan keyakinan nasabah berkontribusi tidak signifikan. Akan tetapi secara simultan semua variabel berkontribusi sangat signifikan. Besaran kontribusinya yaitu 40,6 \%. Yang paling dominan berkontribusi adalah variabel motif rasional.
\end{abstract}

Kata Kunci: Motif, Keyakinan, Minat, Asuransi Syariah

\section{PENDAHULUAN}

Kehadiran lembaga asuransi syari'ah di suatu daerah tentu menambah dinamisasi kompetisi bagi perasuransian di suatu daerah tersebut karena disamping menjadi pesaing baru bagi semua kelembagaan sejenis dan lebih khususnya bagi lembaga asuransi konvensional karena lembaga asuransi syari'ah hadir sebagai alternative baru bagi masyarakat khususnya masyarakat muslim yang menginginkan untuk berasuransi secara syar'i sesuai ajaran Islam.

Asuransi syariah adalah usaha saling melindungi dan tolong menolong diantara sejumlah orang melalui investasi untuk bersama sama menghadapi suatu resiko tertentu yang diikat melalui sebuah akad (kesepakatan) yang tidak melanggar aturan syariah. Bentuk investasi yang dilakukan adalah dalam wujud dana asset atau dana tabarru' (tolong menolong). (Muhammad Syakir Sula:2004). Gemala Dewi mengemukakan bahwa berdirinya asuransi berbasis syariah ini dimaksudkan untuk menciptakan suatu masyarakat yang saling membantu dan saling menopang satu sama lain. (Gemala Dewi:2004). 
Berdasarkan data statistik Industri Keuangan Non Bank (IKNB) syariah yang dirilis Otoritas Jasa Keuangan (OJK), total asset usaha asuransi syariah pada bulan November 2017 mengalami kenaikan dibandingkan tahun lalu yaitu sebesar Rp. 6,13 triliun. Demikian juga asset produktif, total kontribusi bruto dan klaim bruto. Untuk asset produktif usaha asuransi syariah mengalami peningkatan sebesar Rp. 5,59 triliun, dan total kontribusi bruto mengalami kenaikan sebesar Rp 1,4 triliun. Sedangkan untuk klaim bruto pada November 2017 mengalami peningkatan dari tahun sebelumnya sebesar Rp 0,31 triliun. Hal ini menunjukkan bahwa walaupun perkembangan asuransi syariah dari tahun ke tahun mengalami peningkatan akan tetapi masih sangat lambat jika dibandingkan dengan konvensional.

Sedangkan menurut data Badan Pusat Statistik (BPS) tahun 2010 jumlah Muslim di Indonesia mencapai 87,18 \% dari jumlah penduduk Indonesia. (Akhsan nai'm dan Hendry syafutra: 2010). Artinya mayoritas penduduk di Indonesia adalah muslim (beragama Islam). Jika mengacu pada kondisi umum asuransi syari'ah secara nasional mengindikasikan bahwa faktor agama pada masyarakat Indonesia yang mayoritas Muslim tidak serta merta berkorelasi positif dengan market share perusahaan asuransi syariah.

Fakta diatas menunjukkan bahwa faktor keyakinan agama atau sering disebut religiusitas tidak terlalu dominan mempengaruhi minat masyarakat Indonesia untuk berasuransi syariah. Hal ini didukung oleh penelitian Broto Judono (Broto Judono:2016). yang hasilnya bukan faktor religiusitas yang terbukti secara langsung mempengaruhi sikap petani dalam memilih pembiayaan di bank syariah, akan tetapi faktor pemahaman rasionalnya. Akan tetapi berbeda dengan penelitian (Sofhian Sofhian:2017), dan penelitian (Leliya:2016), didapatkan religiusitas berpengaruh positif dan signifikan terhadap keputusan nasabah dalam memilih asuransi syariah.

Minat dapat diartikans ebagai suatu keinginan terhadap sesuatu yang muncul dari dalam individu yang bisa diukur dengan faktor-faktor yang menentukan minat individu. Minat konsumen dapat dimantapkan dengan memperhatikan beberapa faktor yang mempengaruhi keputusan konsumen dalam hal ini nasabah asuransi syariah, antara lain: 1) Faktor psikis (psikologis), yang merupakan faktor pendorong dari dalam diri konsumen. Kotler mengemukakan bahwa faktor psikologis konsumen didasari oleh adanya motivasi, persepsi, pembelajaran, kepercayaan dan sikap yang bisa membuat konsumen melakukan pembelian. (Philip Kotler dan kevin:2009). 2) Faktor sosial, yang merupakan faktor pendorong dari luar diri konsumen. Dalam faktor sosial ini perilaku konsumen dalam melakukan pembelian didasari oleh adanya pengaruh dari keluarga, status sosial dan kelompok acuan konsumen tersebut.

Pada penelitian yang membahas tentang faktor psikologis dan social dalam mempengaruhi minat berasuransi syariah dilakukan oleh (Rahma Liani: 2017), Dari hasil penelitian tersebut 
Rosyidah. Kontribusi Motif Dan Keyakinan Nasabah Pada Pemantapan Minat Berasuransi Syariah di Lombok.

dijelaskan bahwa variabel tingkat religiusitas, kelompok referensi dan besaran premi secara simultan mempengaruhi minat masyarakat dalam memilih asuransi berbasis syariah. Namun secara parsial variabel kelompok referensi secara parsial tidak berpengaruh secara positif dan signifikan pada minat masyarakat dalam memilih asuransi. Hal ini dikarenakan masyarakat tidak menjadikan pedoman bahwa nasehat dan informasi mengenai asuransi syariah yang disampaikan oleh kelompok referensi seperti lingkungan tempat tinggal, orang tua, keluarga, rekan kerja dan lainlain terhadap minat menggunakan asuransi berbasis syariah.

Berdasarkan hal di atas peneliti ingin meneliti lebih mendalam tentang faktor psikologis nasabah yang merupakan faktor pendorong dari diri nasabah yang dapat berkontribusi dalam mempengaruhi minat untuk berasuransi syariah di Lombok.Faktor psikologis yang digunakan dalam penelitian ini hanya motif dan keyakinan nasabah.

Motif menurut Akyas Azhari merupakan suatu daya kekuatan yang mendorong dari dalam diri seseorang untuk berbuat sesuatu atau bertingkah laku untuk mencapai tujuan yang diinginkan. (Akyas Azhari:2004). Sedangkan keyakinan merupakan suatu sikap atau kesadaran yang muncul yang didasarkan atas keyakinan atau kepercayaan seseorang terhadap suatu agama.

Saat ini perkembangan perusahaan asuransi syariah di Lombok sangat menggembirakan. Perusahaan asuransi syariah baik yang beroperasi murni syariah dan membuka unit layanan syariah yaitu: Asuransi Takaful Indonesia, Asuransi Takaful Keluarga, Kantor cabang Asuransi Mubarokah, PT. Life Insurance Sharia Al Amin, AJB Bumi Putra 1912 Kantor Cabang Syariah Mataram, Asuransi Jasindo Takaful, PT. Askrindo (Persero) unit Syariah, PT. Asuransi Bangun Askrida Syariah, PT. Asuransi Allianz Life Indonesia cabang Mataram, PT. Asuransi Jasaraharja Putera (JP- Insurance), PT. Generali Indonesia unit syariah, PT. Sun Life Financial Indonesia Agency Syariah, dan PT. Jamkrindo Syariah.

Melihat perkembangan lembaga asuransi syari'ah di Lombok saat ini cukup signifikan tersebut dapat menjadi indikasi kuat bahwa minat masyarakat Lombok untuk memanfaatkan jasa asuransi syari'ah terus meningkat, dan kemungkinan ada hubungan dengan aspek keyakinan/agama sebagai faktor dari minat berasuransi syari'ah di masyarakat Lombok yang mayoritas muslim.

Hal ini sesuai dengan hasil wawancara yang dilakukan dengan salah satu agen SunLife Financial Syariah di Lombok Timur yang menyatakan bahwa faktor yang menyebabkan nasabah mengambil produk Brilliance Hasanah Fortune Plus dan investasi Salam Equity adalah karena perpaduan konsep asuransi dan investasi berbasis syariah. (Mashur:2018). Demikian juga wawancara dengan staf Askrindo Syariah yang menyatakan bahwa faktor yang mendorong nasabah melakukan investasi di perusahaannya karena sesuai syariah. Wawancara juga dengan salah satu staf 
Asuransi Syariah Al Amin yang menyatakan bahwa faktor yang mendorong nasabah melakukan investasi di Asuransi syariah karena sistem bagi Hasilnya. (Megi:2016)

Dugaan ini diperkuat oleh hasil penelitian yang dilakukan oleh (Muhammad Johari:2018).yanghasil penelitian tersebut diperoleh kesimpulan bahwa Respon masyarakat muslim kota Mataram terhadap asuransi syariah secara keseluruhan adalah positif.

Oleh karena itu selain ingin mengetahui apakah motif dan keyakinan nasabah berkontribusi secara parsial dan simultan pada pemantapan minat nasabah berasuransi syariah di Lombok, peneliti juga ingin mengetahui apakah faktor keyakinan nasabah di Lombok yang tingkat komitmen religius masyarakat Islamnya tinggi (Aker, David:1998). mempunyai kontribusi yang dominan atau tidak.

\section{METODE PENELITIAN}

Populasi dari penelitian ini adalah seluruh nasabah dari lembaga asuransi syariah dilombok. Adapun Sampel yang dipilih adalah 100 nasabah asuransi syariah. Sesuai dengan pendapat (Aaker dan david:1998) bahwa jumlah minimum sampel yang diambil dalam suatu penelitian adalah 100 responden. (Sugihata:2003). Menurut Sugiharto bahwa dengan menggunakan suatu prosedur tertentu dalam menentukan jumlah sampel, hal tersebut diharapkan bisa mewakili populasinya. (Sugiono:2001).

Dalam penelitian ini untuk menentukan sampel menggunakan teknik non probability sampling, yaitu teknik yang tidak memberi kesempatan yang sama bagi anggota populasi untuk dipilih menjadi sampel. (Sugiono:2001).Sedangkan pemilihan sampel dalam penelitian ini dilakukan secara accidental sampling (accidental sampling methods), yaitu pengambilan elemenelemen yang dimasukkan kedalam sampel dilakukan secara kebetulan saja akan tetapi sampel tersebut bersifat representative.Pengukuran kuesioner digunakan skala Likert's yaitu pengukuran kuesioner berdasarkan respon seseorang tentang obyek socialdimana tiap instrumentjawaban mempunyai gradasi dari sangat positif sampai sangat negative.Variabel dan indikator variabel dalam penelitian ini dapat dilihat dibawah ini:

Tabel 1. Variabel Penelitian

\begin{tabular}{ll}
\hline Variabel Penelitian & \multicolumn{1}{c}{ Indikator Penelitian } \\
\hline Motif Rasional & $\begin{array}{l}\text { Peningkatan pendapatan, tahan lama, murah dalam pembelian, } \\
\text { kesempatan investasi, perlindungan, nilai tambah ekonomi }\end{array}$ \\
Motif Emosional & $\begin{array}{l}\text { Kebanggaan pribadi, pencapaian status social, gaya hidup, kenyamanan, } \\
\text { keamanan dan kesehatan }\end{array}$ \\
Keyakinan Nasabah & Aqidah, syari'ah, ilmu pengetahuan agama, pengalaman atau \\
\hline
\end{tabular}




\begin{tabular}{|c|c|}
\hline Variabel Penelitian & Indikator Penelitian \\
\hline $\begin{array}{l}\text { Minat } \\
\text { Syariah }\end{array}$ & $\begin{array}{l}\text { penghayatan, serta pengamalan. } \\
\text { Keaktifan dalam mencari informasi, pengidentifikasian,menganalisis } \\
\text { dan membuat daftar tabel sesuatu yang di minati, dan menetapkan } \\
\text { bidang yang diminati. }\end{array}$ \\
\hline
\end{tabular}

\section{HASIL PENELITIAN}

\section{Pengujian Asumsi Klasik}

a. Uji Normalitas

Uji normalitas digunakan untuk mengetahui apakah variabel bebas dan terikat mempunyai distribusi normal atau tidak, maka dapat dilihat pada gambar normal curve P-Plot sebagai berikut:

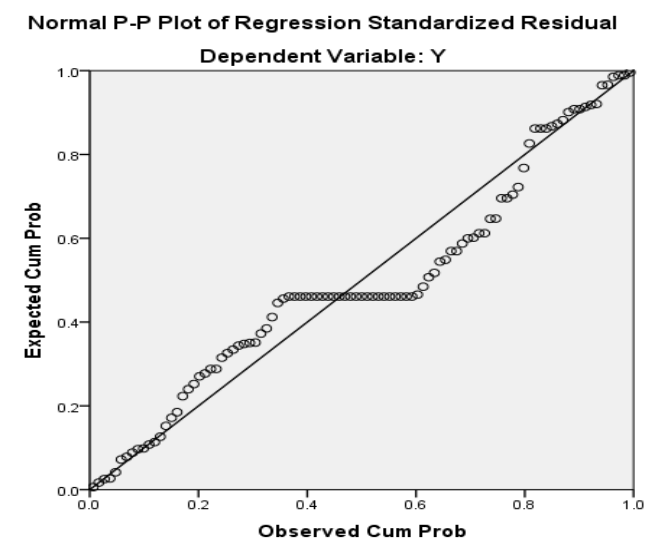

Berdasarkan hasil gambar kurva normal P-P Plot diatas menunjukkan variabel bebas dan terikat mempunyai distribusi data normal atau asumsi normalitas terpenuhi.

b. Uji Multikolinearitas

Uji multikolinearitas digunakan untuk mendeteksi apakah ada kemiripan pada variabel independent, karena apabila antara variabel independent memiliki kemiripan maka akan menyebabkan korelasi yang sangat kuat.

Berdasarkan tabel2 bahwa:

1) Nilai VI Funtuk variabel $\mathrm{X} 1$ sebesar 1.458 atau kurang dari 10, maka variabel $\mathrm{X} 1$ dinyatakan tidak ada gejala multikolinieritas.

2) Nilai VI Funtuk variabel X2 sebesar 1.469 atau kurang dari 10, maka variable X2 dinyatakan tidak ada gejala multikolinieritas

3 ) Nilai VI Funtuk variable X3 sebesar $1.009<10$. Sehingga variabel X3 dinyatakan tidak 
ada gejala multikolinieritas

Jadi Nilai VIF seluruh variabel bebas kurang dari 10 sehingga disimpulkan bahwa seluruh variabel bebas tidak terjadi Multikolinearitas.

\section{Tabel 2.Hasil Uji Multikolinearitas}

\begin{tabular}{lcc}
\hline Model & \multicolumn{2}{c}{ Collinearity Statistics } \\
& Tolerance & VIF \\
(Constant) & & \\
x1 & .686 & 1.458 \\
x2 & .681 & 1.469 \\
X3 & .991 & 1.009 \\
\hline
\end{tabular}

c. Uji Heteroskedastisitas

Uji heterokedastisitas bertujuan untuk mengetahui apakah nilai variance kesalahan pengganggu atau residual bersifat konstan. Hasil uji heteroskedastisitas dapat dilihat pada gambar sebagai berikut:

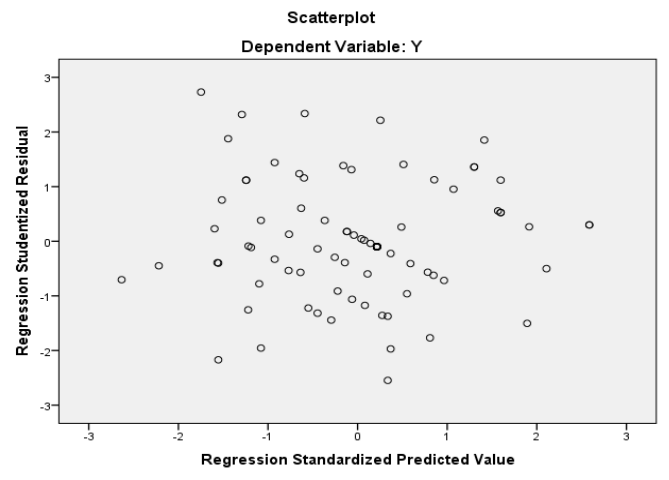

Berdasarkan gambar diatas terlihat tidak adanya pola yang jelas, titik-titik menyebar diatas dan dibawah angka pada sumbu Y. Jadi dapat disimpulkan semua variable independen yang terdapat dalam model ini memiliki sebaran varian yang homogen. Hal ini menunjukkan bahwa tidak terjadi heteroskedastisitas.

d) Uji Autokorelasi

Uji autokorelasi dapat dilakukan dengan menggunakan uji Durbin Watson yaitu dengan melihat koefisien korelasi DW.Kriteria jika du $<\mathrm{d}$ hitung $<4-$ du maka tidak terjadi autokorelasi.

Berdasarkan hasil uji didapatkan nilai Nilai durbin watsonadalah 1.668. Durbin Watson (k. n) jadi (3.100) (k adalah jumlah variabel independent) diperoleh nilai du dan dl maka jika nilai du dan dl adalah 1.613 dan 1.736. maka nilai autokorelasi diantara $1.613<$ 
$1.668<2.387$ jadi tidak terjadi autokorelasi.

\section{Pengujian Validitas Dan Reliabilitas Instrument}

a. Variabel Motif Rasional

Tabel 3Hasil Uji Validitas dan Realiability Variabel $\mathbf{X}_{1}$

\begin{tabular}{ccc}
\hline Item & Koefisien Korelasi & Validitas \\
\hline & Motif Rasional $\left(\mathbf{X}_{\mathbf{1}}\right)$ & \\
$\mathbf{1 .}$ & .314 & Valid \\
$\mathbf{2 .}$ & .215 & Valid \\
$\mathbf{3 .}$ & .452 & Valid \\
$\mathbf{4 .}$ & .422 & Valid \\
$\mathbf{5 .}$ & .214 & Valid \\
$\mathbf{6 .}$ & .251 & Valid \\
$\mathbf{7 .}$ & .222 & Valid \\
Variabel & Koefisien Realiabilitas & Realiabilitas \\
Motif Rasional & 0.600 & Realiable \\
\hline
\end{tabular}

Validitas instrument penelitian dikatakan valid apabila nilai korelasi $>$ dari nilai $\mathrm{r}$ dalam tabel product-moment. Tabel kritis nilai $\mathrm{r}$ tabel adalah 0.165.Berarti dapat disimpulkan bahwa semua item pernyataan motif rasional diatas adalah valid.

Untuk reliability variabel motif rasional sebesar 0.600 menunjukkan kehandalan instrument atau reliable. Karena jika alpha atau $\mathrm{r}$ hitung $=0.60-0.799$ dikategorikan reliabilitas diterima.

b. Variabel Motif Emosional

Tabel 4Hasil Uji Validitas dan Realiability Variabel $\mathbf{X}_{2}$

\begin{tabular}{ccc}
\hline Item & Koefisien Korelasi & Validitas \\
\hline $\mathbf{1 .}$ & Motif Emosional (X2) & \\
$\mathbf{2 .}$ & .467 & Valid \\
$\mathbf{3 .}$ & .688 & Valid \\
$\mathbf{4 .}$ & .733 & Valid \\
$\mathbf{5 .}$ & .418 & Valid \\
$\mathbf{6 .}$ & .598 & Valid \\
$\mathbf{7 .}$ & .291 & Valid \\
Variabel & .252 & Valid \\
Motif Emosional & Koefisien Realiabilitas & Realiabilitas \\
& 0.734 & Realiable
\end{tabular}

Validitasi instrument penelitian dikatakan valid apabila nilai korelasi $>$ dari nilai $\mathrm{r}$ dalam tabel product-moment. Tabel kritis nilai $\mathrm{r}$ tabel adalah 0.165. Berarti dapat disimpulkan bahwa semua item pernyataan motif emosional diatas adalah valid 
Untuk reliability variabel motif emosional sebesar 0.734 menunjukkan kehandalan instrument atau reliable. Karena jika alpha atau $\mathrm{r}$ hitung $=0.60-0.799$ dikategorikan reliabilitas diterima.

c. Variabel Keyakinan Nasabah

Validitas instrument penelitian dikatakan valid apabila nilai korelasi $>$ dari nilai $\mathrm{r}$ dalam tabel product-moment. Tabel kritis nilai $\mathrm{r}$ tabel adalah 0.165 . Sementara nilai hasil korelasi item yang paling rendah pada tabel diatas adalah 0,170 . Berarti dapat disimpulkan bahwa semua item pernyataan keyakinan nasabah diatas adalah valid

Tabel. 5. Hasil Uji Validitas dan Realiability Variabel $\mathbf{X}_{3}$

\begin{tabular}{ccc}
\hline Item & Koefisien Korelasi & Validitas \\
\hline $\mathbf{1 .}$ & Keyakinan Nasabah (X3) & \\
$\mathbf{2 .}$ & .596 & Valid \\
$\mathbf{3 .}$ & .760 & Valid \\
$\mathbf{4 .}$ & .687 & Valid \\
$\mathbf{5 .}$ & .722 & Valid \\
$\mathbf{6 .}$ & .170 & Valid \\
$\mathbf{7 .}$ & .515 & Valid \\
Variabel & .561 & Valid \\
Keyakinan & Koefisien Realiabilitas & Realiabilitas \\
\hline
\end{tabular}

Untuk reliability variable keyakinan nasabah sebesar 0.794 menunjukkan kehandalan instrument atau reliable. Karena jika alpha atau $\mathrm{r}$ hitung $=0.60-0.799$ dikategorikan reliabilitas diterima.

d. Variabel Minat Nasabah

Tabel 6.Hasil Uji Validitas dan Realiability Variabel Y

\begin{tabular}{ccc}
\hline Item & Koefisien Korelasi & Validitas \\
\hline & Minat Nasabah (Y) & \\
$\mathbf{1 .}$ & .550 & Valid \\
$\mathbf{2}$ & .587 & Valid \\
$\mathbf{3 .}$ & .563 & Valid \\
$\mathbf{4}$. & .586 & Valid \\
$\mathbf{5 .}$ & .598 & Valid \\
Variabel & Koefisien Realiabilitas & Realiabilitas \\
Minat Nasabah & 0.794 & Realiable \\
\hline
\end{tabular}

Validitas instrument penelitian dikatakan valid apabila nilai korelasi $>$ dari nilai $\mathrm{r}$ dalam tabel product-moment. Tabel kritis nilai $\mathrm{r}$ tabel adalah 0.165 . Sementara nilai hasil korelasi item yang paling rendah pada tabel diatas adalah 0,550 . Berarti dapat disimpulkan bahwa semua item pernyataan minat nasabah diatas adalah valid 
Rosyidah. Kontribusi Motif Dan Keyakinan Nasabah Pada Pemantapan Minat Berasuransi Syariah di Lombok.

Untuk reliability varia berminat nasabah hitung $=0.60-0.799$ dikategorikan reliabilitas diterima.

\section{PEMBAHASAN}

\section{Motif Rasional Dan Minat Berasuransi Syariah Di Lombok}

Untuk mengetahui apakah variabel Motif Rasional secara parsial berpengaruh terhadap variabel Minat berasuransi syari'ah, maka perlu pengujian dengan uji t. Pada tabel output Coefficient

Tabel 7.Data Hasil Uji Koefisien Regresi Parsial

\begin{tabular}{|c|c|c|c|c|c|}
\hline \multicolumn{6}{|c|}{ Coefficients $^{\mathrm{a}}$} \\
\hline & \multicolumn{2}{|c|}{$\begin{array}{c}\text { Unstandardized } \\
\text { Coefficients }\end{array}$} & \multirow{2}{*}{\multicolumn{3}{|c|}{$\begin{array}{c}\text { Standardized } \\
\text { Coefficients } \\
\text { Beta }\end{array}$}} \\
\hline & B & Std. Error & & & \\
\hline (Constant) & -.501 & .695 & & -.721 & .473 \\
\hline $\mathrm{x} 1$ & .662 & .136 & .469 & 4.854 & .000 \\
\hline $\mathrm{x} 2$ & .287 & .116 & .239 & 2.466 & .016 \\
\hline X3 & .146 & .104 & .113 & 1.401 & .165 \\
\hline a. Dependent V & le: Y & & & & \\
\hline
\end{tabular}

Dari tabel diatas diperoleh hasil pengujian yang menunjukkan t hitung sebesar 4.854 dan signifikansinya adalah 0.000 atau dibawah tingkats ignifikansi 0.05. Hasil ini berarti bahwa hipotesis pertama yang menyatakan bahwa "Motif Rasional" (X1) berkontribusi signifikan terhadap "Minat Nasabah" (Y) diterima. Jadi secara parsial "Motif Rasional” (X1) berkontribusi signifikan pada pemantapan minat berasuransi syariah. Dengan demikian berarti hipotesis $\left(\mathrm{HA}_{1}\right)$ terdukung. Artinya semakin meningkat motif rasional maka semakin besar kontribusinya mempengaruhi minat nasabah untuk berasuransi syariah.

Pada tabel Uji t tersebut menunjukkan bahwa motif rasional memberikan pengaruh atau kontribusi paling dominan pada Pemantapan Minat Nasabah dibandingkan dengan variabel bebas yang lain dengan nilai Coefficients ${ }^{\mathrm{a}}$ padaX1 sebesar 0.662 dengan tingkat signifikasi tertinggi yaitu 0.000. Dengan demikian hipotesis kelima yang menduga faktor keyakinan nasabah yang paling dominan berkontribusi dalam pemantapan minat berasuransi syariah di Lombok tertolak.Motif rasional adalah cara berpikir seseorang dalam memutuskan sesuatu dengan pertimbangan akal sehat. Muncul karena pertimbangan logika. Hal ini menunjukkan apabila ada beberapa pertimbangan alasan logis dan masuk akal maka nasabah akan mempertimbangkan untuk mengambil keputusan berasuransi syari'ah. Alasan rasional tersebut seperti asuransi syariah bisa memberikan pengembalian investasi yang menarik dan optimal sehingga menguntungkan. Dana investasi tetap aman walaupun tidak ada klaim karena asuransi syari'ah menggunakan konsep 
titipan, pengelolaan dana di asuransi syariah transparan dengan konsep system bagi hasil (mudharabah) yang nilainya lebih tinggi dibandingkan menabung dengan deposito. Selain menguntungkan dan aman para nasabah juga menyakini bahwa biaya premi pada asuransi syari'ah lebih murah.

Pikiran-pikiran rasional yang telah digambarkan diatas sebagai dasar motif dalam memantapkan minat untuk berasuransi syari'ah merupakan suatu hal atau tindakan yang secara teoritis dapat dibuktikan kebenarannya, artinya data pendukung berupa hasil kuantitatif didukung juga secara teori sebagaimana pendapat para ahli antara lain ; 1). Nugroho J. Setiadi, motif yang berdasarkan rasional akan menentukan pilihan terhadap suatu produk dengan memikirkan secara matang serta dipertimbangkan terlebih dahulu untuk membeli produk tersebut. Kecenderungan yang akan dirasakan oleh konsumen terhadap produk tersebut adalah sangat puas. (Nugroho:2008). 2). Sementara itu, Nessim dan Richard mengemukakan bahwa (Nessim Hanna dan Richard Wozniak:2001). dan motif rasional ditimbulkan karena pertimbangan alasan dan logika. Hal ini ditekankan pada kriteria yang bersifat objektif, tujuan yang bermanfaat seperti faktor ekonomi, daya tahan, kualitas, dan dapat dipertanggungjawabkan.

Hal ini sesuai dengan penelitian dari Leliya dan Maya K (2016), yang menyatakan bahwa Asuransi syariah Prudential lebih menguntungkan karena sistem bagi hasilnya bisa lebih besar dari konvensional, dan di syariah lebih aman. tidak mengenal istilah dana hangus, bisa mendapatkan uangnya kembali meskipun belum datang jatuh tempo karena menggunakan konsep wadiah (titipan). Asuransi syariah dengan perjanjian diawal yang jelas dan transparan serta akan dikelola secara profesional melalui investasi syariah. Faktor lain yang mendorong seseorang berminat menjadi nasabah pada Prudential adalah reputasi, Proteksi, investasi.

Senada dengan itu adalah penelitian yang dilakukan oleh (Minat iningsih: 2016) yang menyatakan 89,6 \% minat menjadi nasabah diasuransi jiwa Bersama (AJB) Bumi putera 1912 Syariah Kantor Cabang Purwokerto secara simultan dipengaruhi oleh Premi Asuransi Dan Kualitas Pelayanan yang merupakan bagian motif rasional. Demikian juga penelitian oleh (Pahruz: 2015) yang dalam penelitiannya variabel kualitas layanan yang merupakan bagian dari motif rasional berpengaruh positif dan signifikan terhadap keputusan nasabah untuk memilih produk asuransi syariah.

Selain motif, faktor psikologis lain yaitu persepsi tentang asuransi dana pendidikan menurut penelitian (Sutomo:2017) juga memiliki pengaruh positif dan signifikan terhadap kesadaran berasuransi dana pendidikan pada asuransi syariah.

Dominannya faktor rasional berkontribusi pada pemantapan minat berasuransi syariah juga didukung oleh penelitian (Hardiwinoto:2011).pada pada lembaga keuangan syariah yang lain yaitu 
Rosyidah. Kontribusi Motif Dan Keyakinan Nasabah Pada Pemantapan Minat Berasuransi Syariah di Lombok.

perbankan ditemukan bukti bahwa faktor rasional merupakan pendorong utama manager merespon perbankan syariah.

Demikian juga uji hipotesis tentang keyakinan nasabah yang paling dominan tidak terdukung, karena hasil analisis menyatakan motif rasional yang paling dominan mempengaruhi minat berasuransi syariah. Hal ini sesuai penelitian (Broto Judono: 2016), yang menyatakan faktor pemahaman rasional pembiayaan syariah yaitu faktor mengejar keuntungan maksimal atau laba usaha mendasari pemahaman petani tentang pembiayaan bank syariah.

\section{Motif Emosional Dan Minat Berasuransi Syariah Di Lombok}

Untuk mengetahui apakah variabel Motif Emosional secara parsial berpengaruh terhadap variabel Minat berasuransi syari'ah, maka dapat dilihat pada tabel 9 yaitu tabel output Coefficient dengan menggunakan SPSS 20.0. Hasil pengujian menunjukkan $t$ hitung sebesar 2.466 signifikannya adalah 0.016 atau dibawah tingkat signifikansi 0.05 .

Dari hasil ini berarti bahwa hipotesis kedua yang menyatakan "Motif Emosional" (X2) berpengaruh signifikan terhadap"Minat Nasabah" (Y) diterima. Jadi secara parsial motif emosional berkontribusi signifikan pada pemantapan minat berasuransi syariah, dengan demikian berarti hipotesis $\left(\mathrm{HA}_{2}\right)$ terdukung.Artinya semakin meningkat motif emosional maka semakin besar kontribusinya mempengaruhi minat nasabah untuk berasuransi syariah.

Motif emosional merupakan pertimbangan-pertimbangan subjektif seperti kebanggaan atas penampilan pribadinya, pencapaian status social, gaya hidup, kenyamanan, keamanan dan kesehatan yang didasarkan oleh hal hal yang sifatnya pribadi, seperti prinsip hidup, idealis, keyakinan, agama dan sejenisnya. Faktor emosional yang menjadi dasar atau alasan dalam memilih asuransi syari'ah diantaranya adalah adanya faktor individu (instriksik) dan faktor dari luar (ekstrinsik). Faktor instrinsik antara lain bahwa para nasabahmerasa puas bisa berinvestasi untuk peningkatan kehidupan yang lebih baik dimasa mendatang. Selain itu faktor ekspektasi dimasa yang akan datang dengan pertimbangan karena asuransi syariah bisa membantu membayar seluruh pembayaran kesehatan, baik yang murah hingga yang mahal. Demikian halnya dengan biaya pendidikan bahwa tujuan berasuransi pada bidang pendidikan agar bisa membantu membayar biaya sekolah anak-anak mereka ketika mereka mengalami kesulitan keuangan.Adapun faktor eksternal yang mendasari minat masyarakat dalam berasuransi syari'ah adalah karena atas dorongan dan saran teman-teman atau saudara terdekat, mengikuti kebiasaan keluarga, karena dekat dengan tempat tinggal dan kesan dari system pelayanan yang dirasakan dari para pegawai asuransi yang melayani dengan cepat, tepat dan dapat dipercaya.

Semua argumentasi diatas merupakan wujud dari motif emosional yang muncul dari setiap 
responden. Hal ini sejalan dengan apa yang diungkapkan oleh para ahli sebagaimana berikut ini: 1) Menurut Sofjan Assauri, faktor-faktor dari motif pembelian emosional terdiri dari: pembeli ingin tampak berbeda dari yang lain, kebanggaan karena penampilan pribadinya, pencapaian status social, dan untuk terhindar dari keadaan bahaya 2) menurut Ali Hasan, faktor-faktor dari motif pembelian emosional terdiri: (Sofjan Assauri:2013). kesenangan, kesederhanaan dan aktivitas, kebanggaan penampilan pribadi, kebanggaan kepemilikan, kerjasama dan empati, keamanan dan kesehatan, dan kenyamanan pribadi.

Berdasarkan hasil penyebaran angket penelitian, sumber informasi tentang asuransi syariah adalah Informasi secara lisan dengan pendekatan personal baik antar teman, keluarga dan hubungan personal lainnya menjadi sistem informasi yang banyak mempengaruhi minat para nasabah yakni sebesar 67\%. Hal ini sesuai dengan penelitian Pahruz (2015), yang hasilnya bahwa kualitas layanan dan Word OfMouth (WOM) berpengaruhpositifdan signifikan terhadapkeputusan nasabah untuk memilih produk asuransi syariah.Senada dengan itu juga penelitian oleh (Edi Hariyadi dan Triyanto:2017) yang menjelaskan bahwa peran agen asuransi syariah diantaranya sebagai akses jembatan informasi yang benar kepada masyarakat tentang asuransi syariah dan memberikan pelayanan yang terbaik sehingga bisa mempengaruhi secara emosional para calon nasabah untuk memantapkan minat memilih asuransi syariah.

Namun berbeda dengan penelitian yang dilakukan Rahma Liani (2017), yang menyatakan untuk variabel kelompok referensi tidak berpengaruh positif dan signifikan terhadap minat masyarakat dalam memilih asuransi berbasis syariah. Hal ini dikarenakan masyarakat tidak menjadikan pedoman bahwa nasehat dan informasi mengenai asuransi syariah yang disampaikan oleh kelompok referensi seperti lingkungan tempat tinggal, orang tua, keluarga, rekan kerja dan lain-lain terhadap minat menggunakan asuransi berbasis syariah.Demikian juga penelitian Hardiwinoto (2011), yang menyatakan faktor emosional bukan merupakan pendorong utama manager merespon perbankan syariah.

\section{Keyakinan Nasabah dan Minat Berasuransi Syariah di Lombok}

Untuk mengetahui apakah variabel keyakinan nasabah secara parsial berpengaruh terhadap variabel Minat berasuransi syari'ah, maka dapat dilihat pada tabel 9 yaitu tabel output Coefficient dengan menggunakan SPSS 20.0. Hasil pengujian menunjukkan t hitung sebesar 1.401 dan signifikansinya adalah 0.165 atau diatas tingkat signifikansi 0.05 .

Dari hasil ini berarti bahwa hipotesis ketiga yang menyatakan keyakinan nasabah (X3) berpengaruh signifikan terhadap pemantapan minat nasabah (Y) ditolak. Jadi secara parsial keyakinan nasabah berpengaruh tidak signifikan terhadap pemantapan minat nasabah, ini berarti 
Rosyidah. Kontribusi Motif Dan Keyakinan Nasabah Pada Pemantapan Minat Berasuransi Syariah di Lombok.

hipotesis $\left(\mathrm{HA}_{3}\right)$ tidak terdukung.Artinya semakin meningkat keyakinan nasabah maka tidak terlalu berkontribusi mempengaruhi minat nasabah untuk berasuransi syariah.

Keyakinan nasabah atau disebut religiusitas nasabah dapat digambarkan sebagai adanya konsistensi antara kepercayaan terhadap agama sebagai unsur kognitif, perasaan agama sebagai unsur afektif dan perilaku terhadap agama sebagai unsur psikomotorik. (Jalaludin:2010).

Para nasabah yang menjadi responden dalam penelitian ini meyakini bahwa Allah maha mengatur dan karenanya setiap hamba harus patuh dan berusaha senantiasa bisa melaksanakan semua jenis ibadah yang telah diwajibkan oleh Allah SWT.Dan sebagai bentuk kepatuhan tersebut para responden merasa bahagia setiap dapat melakukan perbuatan yang benar menurut Agamanya (Islam).

Demikian halnya dalam berinvestasi, para nasabah (responden) dalam berinvestasi akan memilih investasi yang sesuai dengan ajaran agama, tidak melanggar ajaran agamanya. (seperti investasi dalam asuransi syariah). Bentuk kesesuaian asuransi dengan ajaran agama yang dimaksudkan adalah antara lain sistem kerja asuransi syariah menganut asas gotong royong, saling membantu antar nasabah. Produk perusahaan asuransi syariah terhindar dari sistem riba, gharar (ketidak jelasan dana), dan maysir (judi) yang dilarang oleh agama. Sehingga dengan demikian para nasabah (responden) tidak perlu kuatir menggunakan asuransi syariah karena dalam menjalankan bisnisnya sudah sesuai dengan peraturan sistem syariah yang adil atau sesuai dengan ajaran agama Islam.

Hal ini didukung oleh teori yang dinyatakan oleh Glock dan Stark merumuskan religiusitas sebagai komitmen religius (berhubungan dengan agama atau keyakinan iman), yang dapat dilihat melalui perilaku individu yang bersangkutan dengan agama atau keyakinan iman yang dianut.Jadi, sikap religiusitas merupakan integrasi secara kompleks antara pengetahuan agama, perasaan serta tindakan keagamaan pada seseorang. Hal senada juga disampaikan oleh Delener (1990) dalam (Esso dan Dibb:2004) yang menyatakan bahwa religiusitas adalah salah satu factor pendorong penting dan dapat berpengaruh terhadap perilaku konsumen.

Hasil analisis itu sesuai dengan penelitian dari Muhammad Johari (2015), Sofhian Sofhian Dan Sri Nur Ain Suleman (2017), Rahma Liani (2017), dan Leliya dan Maya K (2016), yang menyatakan bahwa faktorreligiusitas ataukeyakinan nasabah berpengaruh positif dan signifikan pada minat atau keputusan nasabah memilih asuransi syariah.

Akan tetapi berdasarkan hasil uji diatas berpengaruhnya tidak signifikan. Hal ini mengindikasikan bahwa faktor keyakinan agama pada masyarakat Lombok yang mayoritas Muslim tidak serta merta berpengaruh secara signifikan dengan minat berasuransisyariah.Senada dengan hal itu juga pada penelitian yang dilakukan oleh Broto Judono (2016), didapatkan bahwa faktor 
religiusitas tidak terbukti secara langsung mempengaruhi sikap petani dalam memilih pembiayaan di bank syariah.

\section{Motif Rasional, Motif Emosional, Keyakinan Nasabah, Dan Minat Berasuransi Syariah Di Lombok.}

Dari Data Hasil Uji F Test, menunjukkan F-hitung sebesar 21.160 dan signifikansinya adalah 0.000 atau dibawahs ignifikansi 0.05 . Hasil ini menunjukkan bahwa variabel independent secara simultan berpengaruh signifikan terhadap variabel dependent. Ini berartibahwa hipotesis yang menyatakan motif rasional, motif emosional, dan keyakinan nasabah secara simultan berkontribusi signifikan terhadap pemantapan minat berasuransi syariah terdukung atau diterima.

Dari Hasil Uji Koefisien Determinasi diperoleh nilai $R$ square $\left(\mathrm{R}^{2}\right)$ sebesar 0.406. Nilai ini menunjukkan pengaruh atau kontribusinya sebesar 40.6\%.Artinya bahwa besarnya kemampuan motif rasional, motif emosional dan keyakinan nasabah dalam mempengaruhi minat berasuransi syari'ah adalah $40.6 \%$. Sisanya 59.4\%dipengaruhi oleh faktor psikologis yang lain dan faktor social yang tidak disebutkan dalam penelitian ini seperti persepsi, pengetahuan, sikap, gaya hidup, kepribadian, lokasi strategis, bauran pemasaran, dan lain-lain.

Minat nasabah berasuransi syariah ini juga dapat dibuktikan berdasarkan hasil dari tabulasi data angket yang menjelaskan bahwa minat masyarakat dalam berasuransi di lembaga asuransi syari'ah tinggi dengan perincian yaitu 15.40\% sangat berminat, $67.00 \%$ menyatakan berminat untuk berasuransi syari'ah. Hal ini karena minat yang dapat diartikan sebagai kecenderungan terhadap sesuatu yang muncul berasal dari individu dan telah menjadi kebiasaan umum dalam lingkungan masyarakat yang bisa diukur dengan factor yang menentukan minat individu.

Jadi minat nasabah berasuransi syariah ini dapat ditingkatkan dengan memperhatikan beberapa faktor, antara lain:1). Faktor psikologis yang merupakan faktor pendorong dari dalam diri konsumen, seperti motivasi dalam penelitian ini adalah motif rasional dan emosional, persepsi, pengetahuan, keyakinan dan sikap. 2). Faktor sosial yang merupakan proses dimana perilaku seseorang dipengaruhi oleh keluarga, status sosial, kelompok acuan, dan pemberdayaan bauran pemasaran (produk, harga, promosi dan distribusi) pada perusahaan asuransi syariah.

Indikator dari sikap yang sudah dilakukan nasabah untuk dapat dikatakan berminat ditandai dengan beberapa hal berikut antara lain; aktif mencari informasi lebih detail tentang asuransi syari'ah, sering membuat perencanaan dan berdiskusi dengan banyak pihak sebelum mengambil keputusan, ketika terjadi masalah seputar asuransi syariah, akan mengidentifikasi dan menganalisis masalah yang muncul tersebut, memahami produk asuransi syariah membuat lebih faham terkait hal tersebut sehingga memudahkan memilih jenis produk asuransi syariah, membuat perbandingan 
Rosyidah. Kontribusi Motif Dan Keyakinan Nasabah Pada Pemantapan Minat Berasuransi Syariah di Lombok.

keunggulan asuransi syariah dan asuransi konvensional.

\section{SIMPULAN}

Berdasarkan analisis yang peneliti lakukan dapat disimpulkan bahwa dari Uji T semua variabel bebas secara parsial berpengaruh terhadap pemantapan minat berasuransi syariah di Lombok.Sehingga hipotesis yang diajukan dalam penelitian ini dapat diterima.Namun variabel keyakinan nasabah tingkat pengaruhnya tidak signifikan. Ini berarti bahwa apabila terjadi peningkatan beberapa pertimbangan alasan logis (objektif) tentang asuransi syariah, pertimbangan subjektif yang bersifat emosional pada nasabah dan komitmen religius maka akan meningkatkan kontribusinya pada minat berasuransi syariah, akan tetapi kontribusi keyakinan nasabah tidak signifikan.

Apabila semua variabel bebas diuji secara simultan maka pengaruhnya positif dan sangat signifikan terhadap variabel terikat.Sehingga hipotesis yang diajukan dalam penelitian ini dapat diterima. Hal ini berarti apabila faktor psikologis seperti motif rasional, motif emosional dan keyakinan nasabah ditingkatkan secara simultan maka akan meningkatkan kontribusinya secara signifikan pada pemantapan minat berasuransi syariah di Lombok. Besaran pengaruh atau kontribusinya sebesar 40.6\%. Artinya bahwa kemampuan motif rasional, motif emosional dan keyakinan nasabah dalam mempengaruhi minat berasuransi syari'ah adalah sebesar $40.6 \%$, sisanya sebesar 59.4\%dipengaruhi faktor yang lain yang tidak disebutkan dalam penelitian. Dari semua variabel bebas yang paling dominan mempengaruhi minat berasuransi syariah adalah motif rasional. Jadi hipotesis yang menduga bahwa faktor keyakinan nasabah yang paling dominan tidak terdukung atau ditolak.

\section{REFERENSI}

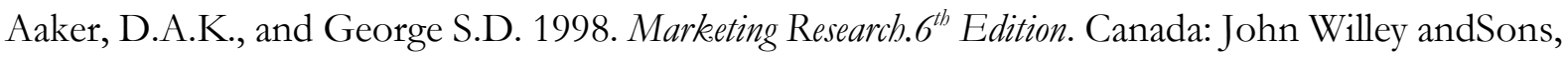
Inc.

Assauri, S. 2013. Manajemen Pemasaran : Dasar, Konsep dan Strategi, ed.1. Jakarta : Rajawali Press.

Azhari, A. 2004. Psikologi Umum dan Perkembangan. Jakarta : Teraju Mizan.

Dewi, G. 2004. Aspek-Aspek Hukum Perbankan dan Perasuransian Syariah di Indonesia. Jakarta: Prenada Media Group.

Essoo, N.D. 2004. Religious Influences on Shopping Behaviour: An Exploratory Study. Journal of Marketing Management. Vol. 20.

Hanna, N. \& Wozniak, R. 2001.Consumer Behavior An Applied Approach. New Jersey : Prentice Hall. 
Hardiwinoto.2011. Analisis Faktor Emosional dan Rasional Dalam Keputusan Pembiayaan Perusahaan Melalui Bank Syariah di Jawa Tengah. JurnalUniversitas Muhamadiyah Semarang. Hariyadi, E.\& Triyanto, A. 2017. Peran Agen Asuransi Syariah Dalam Meningkatkan Pemahaman Masyarakat Tentang Asuransi Syariah. Jurnal Ekonomi Dan Perbankan Syariah. SEBI vol.5 No. 1

Hasan, A. 2010. Marketing Bank Syariah. Bogor: Ghalia Indonesia.

Jalaluddin. 2010. Psikologi Agama. Jakarta : PT. Raja Grafindo Persada.

Johari, M . 2015. Respon Masyarakat muslim Kota Mataram Terbadap Asuransi Syariah. Thesis UIN Sunan Kalijaga, Yogjakarta.

Judono, B. 2016. Pengaruh Pemahaman Rasional Pembiayaan Syariah Dan Religiusitas Petani Terhadap Sikap Petani Dalam Memilih Bank Syariah. Jurnal Manajemen dan Kewirausahaan Vol.4 No.1

Kotler, P.,\& Keller, K.L. 2009. Manajemen Pemasaran. Terj. Benyamin Molan, Edisi 12 Jilid 1.. Jakarta: PT. Indeks.

Leliya dan Kurniawati, M. 2016. Minat Masyarakat Berasuransi Syariah di Asuransi Prudential. Jurnal Orasi LAIN Syekh Nurjati Cirebon. I (2).

Liani, R. 2017. Analisis Faktor-Faktor Yang Mempengarubi Minat Masyarakat Dalam Memilih Asuransi berbasis syariah. Skripsi UIN sunan Kalijaga. Jogjakarta.

Minatiningsih, C. 2016. Pengaruh Premi Asuransi Dan Kualitas Pelayanan Terhadap Minat Menjadi Nasabah Asuransi Jiwa Bersama (AJB) Bumiputera 1912 Syariah Kantor Cabang Purwokerto. Skripsi UIN Sunan Kalijaga. Yogyakarta.

Na’im, A. \& Syaputra, H. 2010.Hasil Sensus Penduduk. Jakarta : Badan Pusat Statistik.

Pahruz. 2015. Pengaruh Kualitas Layanan, Kontribusi Dan Word Of Mouth (Wom) Terbadap Keputusan Nasabah Untuk Memilih Produk. Asuransi Syariah (Studi Kasus Pada PT. Asuransi Takaful Keluarga Cabang Yogyakarta. Skripsi UIN Sunan Kalijaga.Yogyakarta.

Setiadi, N.J. 2008. Perilaku Konsumen : Konsep dan Implikasi untuk. Strategi dan Penelitian Pemasaran, edisi 1 Cet. 3. Jakarta : Kencana.

Singarimbun, M.,\& Efendi,S. 1989. Metodologi Penelitian Survai, ed. Revisi. Jakarta : LP3ES.

Sofhian, S., \&Suleman, S.N.A. 2017. Pengaruh Kualitas Produk Dan Religiusitas Terhadap Keputusan Nasabah Dalam Memilih Asuransi Syariah Di PT. Prudential Life Anssurance Cabang Kota Gorontalo. Jurnal Li Falah FEBI LAIN Kendari.

Sugiharto. 2003. Teknik Sampling. Jakarta : PT. Gramedia Pustaka Utama.

Sugiyono.2001. Statistik Untuk Penelitian. Bandung:Alfabeta 
Rosyidah. Kontribusi Motif Dan Keyakinan Nasabah Pada Pemantapan Minat Berasuransi Syariah di Lombok.

Sula, M.S. 2004. Asuransi Syariah (life dan general) Konsep dan Sistem Operasional, cet. Ke - 1.Jakarta : Gema Insani Press.

Sutomo, 2017.Persepsi dan Kesadaran Berasuransi Dana Pendidikan Syariah Orang Tua Peserta Didik Madrasah Aliyah."Jurnal Saintifika islamica Volume 2 No. 1 